\title{
Transport of glycine betaine in the extremely haloalkaliphilic sulphur bacterium Ectothiorhodospira halochloris
}

\author{
Petra Peters, ${ }^{1 *}$ Elisha Tel-Or ${ }^{2}$ and Hans G. TrüPeR ${ }^{1}$ \\ ${ }^{1}$ Institut für Mikrobiologie \& Biotechnologie, Rheinische Friedrich-Wilhelms-Universität Bonn, Meckenheimer Allee 168, \\ 5300 Bonn 1, Germany \\ ${ }^{2}$ The Hebrew University of Jerusalem, Faculty of Agriculture, Department of Agricultural Botany, PO Box 12, \\ Rehovot 76-100, Israel
}

(Received 13 March 1992; revised 18 June 1992; accepted 23 June 1992)

\begin{abstract}
The effect of osmotic stress on the transport of the compatible solute glycine betaine was examined in Ectothiorhodospira halochloris, an extremely haloalkaliphilic, phototrophic sulphur bacterium. Kinetic data indicated that $E$. halochloris possesses an active transport system for glycine betaine which is saturable and exhibits Michaelis-Menten kinetics. Experiments with chloramphenicol-treated cells (50 $\mu \mathrm{g} \mathrm{per} \mathrm{ml}$ of cell suspension) indicated that the transport system is constitutive and might be activated by a change in osmotic pressure. The uncouplers carbonyl cyanide $m$-chlorophenylhydrazone (CCCP) and carbonyl cyanide $p$-(trifluoromethoxy)phenylhydrazone (CCFP) totally blocked uptake at concentrations of $25 \mu \mathrm{M}$ and $100 \mu \mathrm{M}$, respectively. The system was insensitive to the cytochrome oxidase inhibitor sodium azide $(1 \mathrm{mM})$, the respiratory chain inhibitor potassium cyanide $(1 \mathrm{mM})$ and the glycolysis inhibitor iodoacetate $(1 \mathrm{mM})$. The ionophore nigericin $(50 \mu \mathrm{M})$ had the greatest inhibitory effect, completely abolishing uptake, while monensin $(100 \mu \mathrm{M})$ caused $80 \%$ inhibition. Glycine betaine transport possessed considerable structural specifity: proline betaine was the most effective competitor and trigonelline and dimethylglycine exerted inhibition to a lesser extent. Transport in the dark was at a greatly reduced rate. These results collectively implied that the specific transport of glycine betaine might be driven by the electrochemical proton gradient generated by anaerobic photosynthesis.
\end{abstract}

\section{Introduction}

Micro-organisms have evolved different strategies in responding to decreased water availability in their natural habitats. Osmotic equilibrium is maintained by either electrolytes (salts) requiring salt-adapted cellular structures or the accumulation of compatible solutes (Brown, 1976). Compatible solutes may be taken up from the surrounding medium or they may be synthesized by the bacteria themselves.

The quarternary amine glycine betaine $(N, N, N-$ trimethylglycine) is an important compatible solute not only in extreme halophiles (Galinski \& Trüper, 1982) but also in Gram-negative, non-halophilic eubacteria (Cairney et al., 1985a,b), moderate halophiles (Imhoff \&

* Author for correspondence. Tel. 228735591 ; fax 228737576.

Abbreviations: CCCP, carbonyl cyanide $m$-chlorophenylhydrazone; CCFP, carbonyl cyanide $p$-(trifluoromethoxy)phenylhydrazone; CDNB, 1-chloro-2,4-dinitrobenzene; DCCD, $N, N^{\prime}$-dicyclohexylcarbodiimide; DNP, 2,4-dinitrophenol; PCMB, p-chloromercuribenzoate.
Rodriguez-Valera, 1984) and halotolerant microorganisms (Ken-Dror et al., 1986). Currently, only three groups seem to be capable of de novo betaine synthesis: cyanobacteria (Borowitzka, 1980; Mohammad et al., 1983; Gabbay-Azaria et al., 1988), some anaerobic photosynthetic bacteria (genus Ectothiorhodospira) and Actinopolyspora halophila (Severin et al., 1992). Transport systems for glycine betaine have been described in Escherichia coli, Salmonella typhimurium and Klebsiella pneumoniae (Le Rudulier \& Bouillard, 1983; Le Rudulier et al., 1982), in Rhizobium meliloti (Fougère \& Le Rudulier, 1990), Rhodobacter sphaeroides (Abee et al., 1990), Lactobacillus acidophilus (Hutkins et al., 1987) and Azospirillum brasilense sp7 (Riou et al., 1991), as well as in some methanogenic bacteria (Robertson et al., 1990).

In E. coli and $S$. typhimurium, two genetically distinct transport systems were identified: a high-affinity system encoded by proU and a low-affinity system encoded by proP (Cairney et al., 1985a; Barron et al., 1987). In $R$. meliloti (Le Rudulier et al., 1991), A. brasilense sp7 (Riou et al., 1991) and E. coli (May et al., 1986) a periplasmic 
binding protein is involved in the transport of glycine betaine.

Ectothiorhodospira halochloris, an extremely haloalkaliphilic phototrophic sulphur bacterium, uses glycine betaine as its main compatible solute in addition to ectoine and trehalose (Galinski \& Trüper, 1982). Glycine betaine cannot be used as carbon, nitrogen or energy source, and it cannot be stored as reserve material. Only its extrusion in response to osmotic stress (downshock) has been investigated (Tschichholz \& Trüper, 1990). The contribution of glycine betaine biosynthesis during adaptation to osmotic changes in comparison to nonstressed cells was investigated by Galinski (1986). Biosynthesis that supplements glycine betaine content after osmotic upshock became obvious after $3 \mathrm{~h}$. The question raised was whether any fast responses like transport processes exist to balance sudden osmotic changes. The current study characterizes the glycine betaine transport system in $E$. halochloris. To provide evidence for the existence of this system we examined saturation kinetics, substrate specifity and the influence of metabolic inhibitors.

\section{Methods}

Organism and culture conditions. Ectothiorhodospira halochloris strain DSM 1059 was grown anaerobically at $40^{\circ} \mathrm{C}$ in 1 litre screw-cap bottles at a light intensity of 10000 lux in a medium according to Imhoff \& Trüper (1977). Acetate and bicarbonate were used as carbon sources. For transport experiments, medium containing $\mathrm{NaCl}, \mathrm{NaHCO}_{3}$, $\mathrm{Na}_{2} \mathrm{CO}_{3}, \mathrm{Na}_{2} \mathrm{SO}_{4}$ and $\mathrm{Na}_{2} \mathrm{~S}$ only at the appropriate concentrations was used. For determination of the $\mathrm{pH}$ optimum, the ratio of $\mathrm{Na}_{2} \mathrm{CO}_{3}$ to $\mathrm{NaHCO}_{3}$ was varied and, if necessary, the $\mathrm{pH}$ adjusted with $\mathrm{H}_{2} \mathrm{SO}_{4}$ or $\mathrm{NaOH}$.

Preparation of $\left[{ }^{14} \mathrm{Clglycine}\right.$ betaine. $\left[1,2-{ }^{14} \mathrm{C}\right]$ Glycine betaine was prepared from $\left[1,2^{14} \mathrm{C}\right]$ choline as described by Ikuta et al. (1977). $\left[{ }^{14} \mathrm{C}\right]$ Choline was enzymically oxidized by the enzyme choline oxidase (EC 1.1.3.17) from an Alcaligenes sp. To purify $\left[{ }^{14} \mathrm{C}\right] \mathrm{glycine}$ betaine, the reaction mixture was ultrafiltrated (Millipore Ultrafree MC, 10000 NMLW filter unit). The filtrate was incubated twice with $150 \mathrm{mg}$ of ion-exchange resin (Galinski, 1987) to separate un-oxidized $\left[{ }^{14} \mathrm{C}\right] \mathrm{cho}-$ line from $\left[{ }^{14} \mathrm{C}\right]$ glycine betaine. The amount of $\left[{ }^{14} \mathrm{C}\right]$ glycine betaine was determined in scintillation vials containing $4 \mathrm{ml}$ of scintillation fluid (Lumagel LSC Cocktail, Baker) in a Beckman liquid scintillation counter (Beckman LS 230 liquid scintillation system).

This result was confirmed by HPLC using a Nucleosil $5 \mathrm{NH}_{2}$ (Macherey and Nagel, Düren, Germany) column and acetonitrile/water $(70: 30, \mathrm{v} / \mathrm{v})$ as solvent. Non-radioactive glycine betaine was monitored using a LDC/Milton Roy HPLC unit with refractive index monitor (model 1109) and integrator (CI-10).

Transport assays. When the culture density reached an $\mathrm{OD}_{650}$ of 1.2 to 1.3 (late exponential growth phase), $25 \mathrm{ml}\left(0.5 \mathrm{mg}\right.$ protein $\left.\mathrm{ml}^{-1}\right)$ of cell suspension was equilibrated for $30 \mathrm{~min}$ in a glass vial $\left(\mathrm{N}_{2}, 40^{\circ} \mathrm{C}\right.$, 10000 lux). Centrifugation was avoided because the cells are sensitive to oxygen. The betaine content of the medium was determined by HPLC (Galinski, 1987) and the ammonium reineckate method (Cromwell \& Rennie, 1953) to exclude any interference from glycine betaine already present in the cell suspension. If not stated otherwise, the cells were shocked from $2 \cdot 1 \mathrm{M}-\mathrm{NaCl}$ to $3 \cdot 1 \mathrm{M}-\mathrm{NaCl}$ either by use of transport medium ( $25 \mathrm{ml}$, prewarmed and gassed) of the appropriate salt concentration or as confirmation of the results by addition of solid $\mathrm{NaCl}$. Temperature and $\mathrm{pH}$ in the transport experiments were identical with the growth conditions $\left(40^{\circ} \mathrm{C}, \mathrm{pH} 8 \cdot 7\right)$ to avoid changing too many parameters. Uptake experiments were started by the addition of shock medium and substrate; if not stated otherwise, $1 \mu \mathrm{M}$ $\left[{ }^{14} \mathrm{C}\right]$ glycine betaine and a defined amount of non-radioactive glycine betaine were used as substrate.

The reaction was terminated by rapid filtration through filters (Whatman GF/F) and the cells were then quickly washed twice with $2 \mathrm{ml}$ of medium of a corresponding salt concentration. The filters were solubilized in scintillation vials containing $4 \mathrm{ml}$ of scintillation fluid.

All data presented are mean values derived from duplicates of three experiments. Unless indicated otherwise, results agreed within less than $5 \%$. The results are expressed as nmol glycine betaine $(\mathrm{mg}$ protein $)^{-1}$; protein was determined by the bicinchoninic acid method (BCA; Pierce, 1989).

In inhibition assays, the cells were pre-incubated with inhibitor for $30 \mathrm{~min}$ before addition of substrate $\left(1 \mu \mathrm{M}-\left[{ }^{14} \mathrm{C}\right]\right.$ glycine betaine, $4 \mathrm{mM}$ non-radioactive glycine betaine). Addition of chloramphenicol $(50 \mu \mathrm{g}$ $\mathrm{ml}^{-1}$ ) required $1 \mathrm{~h}$ pre-incubation, PCMB was incubated for $10 \mathrm{~min}$ and CDNB for $15 \mathrm{~min}$. If ethanol (no more than $2 \%$ of the cell suspension) was used as solvent (for ionophores and DCCD) the effect of ethanol itself was also tested. Detailed information about the effect of ionophores and DCCD on E. halochloris is provided by Meyer (1987).

The influence of dark conditions was tested by wrapping the vial with aluminium foil during pre-incubation and uptake measurements.

In competition experiments, a mixture of labelled substrate $(1 \mu \mathrm{M}-$ $\left[{ }^{14} \mathrm{C}\right]$ glycine betaine) and unlabelled analogue was added.

In order to test the range of salt stress that $E$. halochloris is able to stand without cell leakage, salt-shocked cell suspensions were centrifuged after different times and the protein content of the supernatant was measured by the method of Warburg \& Christian (1941) and by the BCA method.

Chemicals. $\left[1,2-{ }^{-14} \mathrm{C}\right]$ choline $\left[7.2 \mathrm{mCi} \mathrm{mmol}^{-1}\left(266 \mathrm{MBq} \mathrm{mmol}^{-1}\right)\right]$ was obtained from DuPont. Choline oxidase, glycine betaine, glycine betaine aldehyde, choline, trigonelline, $\gamma$-butyrobetaine, $\gamma$-amino- $n$ butyrate, L-alanine, 2,4-dinitrophenol, iodoacetate, chloramphenicol, sodium azide, nigericin, valinomycin, monensin, CCCP, CCFP, PCMB, CDNB, 1-chloromercuriphenyl sulphonic acid were purchased from Sigma. Potassium cyanide was purchased from E. Merck.

Proline betaine (stachydrine) was kindly provided by D. Le Rudulier, University of Nice, France.

\section{Results and Discussion}

\section{Growth in the presence of exogenous glycine betaine and effect of increased osmolarity}

Addition of $5 \mathrm{~mm}$-glycine betaine to the growth medium stimulated the growth rate of $E$. halochloris, especially at high salt concentrations. For example, at $2.4 \mathrm{M}-\mathrm{NaCl}$ there was a $9 \%$ stimulation $\left(0.054 \mathrm{~h}^{-1}\right.$ to $\left.0.059 \mathrm{~h}^{-1}\right)$ and at $3.8 \mathrm{M}-\mathrm{NaCl}$ a $19 \%$ stimulation $\left(0.031 \mathrm{~h}^{-1}\right.$ to $\left.0.037 \mathrm{~h}^{-1}\right)$. Choline and glycine, considered as possible biosynthetic precursors of glycine betaine (Oren, 1990), had no effect. $E$. halochloris was able to stand sudden salt changes 


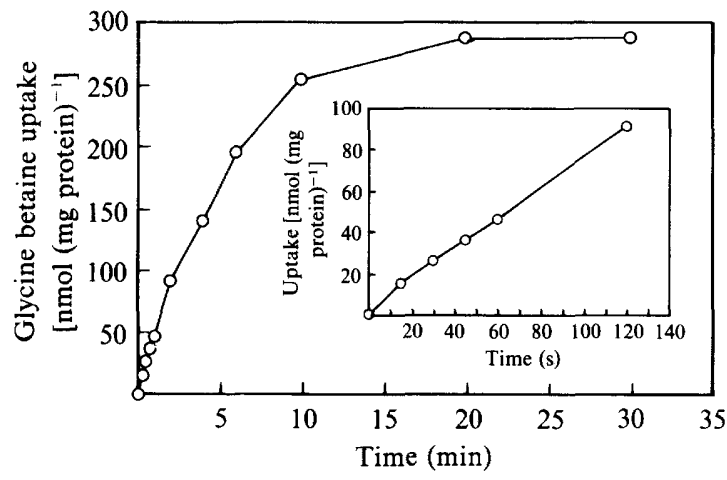

Fig. 1

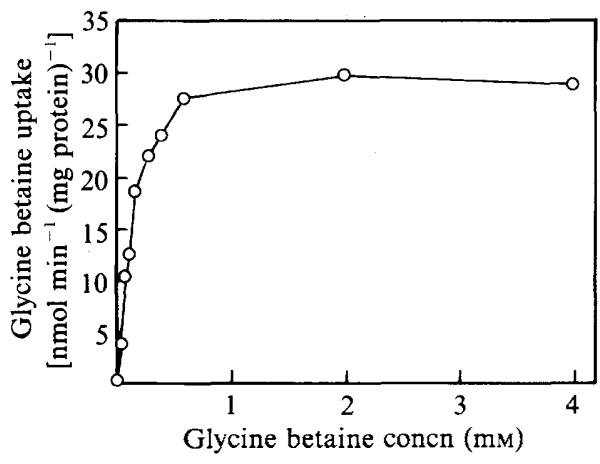

Fig. 2

Fig. 1. Time-dependent uptake of glycine betaine by $E$. halochloris, performed as described in Methods with 4 mM-glycine betaine at $40^{\circ} \mathrm{C}$ and $\mathrm{pH} \mathrm{8.7.} \mathrm{The} \mathrm{insert} \mathrm{shows} \mathrm{transport} \mathrm{during} \mathrm{the} \mathrm{first} 2 \mathrm{~min}$.

Fig. 2. Kinetics of glycine betaine transport by E. halochloris. Uptake was measured as described in Methods at $40^{\circ} \mathrm{C}$ and $\mathrm{pH} 8 \cdot 7$.

(upshock) of $1.0 \mathrm{M}-\mathrm{NaCl}$ without obvious cell damage (release of proteins). For calculating the cytoplasmic solute concentrations, cytoplasmic volume values of $257 \mu \mathrm{l}(\mathrm{g} \text { pellet wt })^{-1}(2 \cdot 1 \mathrm{M}-\mathrm{NaCl})$ and $210 \mu \mathrm{l}$ (g pellet $\mathrm{wt})^{-1}(3 \cdot 1 \mathrm{M}-\mathrm{NaCl})$ were used (Galinski, 1986). HPLC measurements yielded a value of $150 \mathrm{~g}$ glycine betaine ( $\mathrm{kg}$ cytoplasmic water) ${ }^{-1}$ (equivalent to 1.0 molal) for cells grown at $2 \cdot 1 \mathrm{M}-\mathrm{NaCl}$ and of $196 \mathrm{~g}$ glycine betaine ( $\mathrm{kg}$ cytoplasmic water) ${ }^{-1}$ (equivalent to 1.6 molal) at $3 \cdot 1 \mathrm{M}-\mathrm{NaCl}$.

\section{Active glycine betaine transport and its kinetics}

Cells of E. halochloris grown anaerobically in the light were able to take up glycine betaine against a concentration gradient after osmotic upshock $(2 \cdot 1 \mathrm{M}$ - to $3 \cdot 1 \mathrm{M}$ $\mathrm{NaCl}$ ). Glycine betaine was not metabolized further. No measurable transport of glycine betaine was observed in the absence of osmotic stress.

Time-dependent measurement of uptake was linear for only $2 \mathrm{~min}$ (Fig. 1). The initial uptake rate at $40^{\circ} \mathrm{C}$, $\mathrm{pH} 8.7$, and $4 \mathrm{~mm}$-glycine betaine was $29 \pm 1 \mathrm{nmol}$ $\min ^{-1}$ (mg protein $)^{-1}$, reaching a level of $288 \pm 8 \mathrm{nmol}$ $(\mathrm{mg} \text { protein })^{-1}$ after $20 \mathrm{~min}$. Transport saturated with respect to substrate concentration (Fig. 2) and followed Michaelis-Menten kinetics. The $K_{\mathrm{m}}$ value (Hanes, 1932) was $60 \pm 2 \mu \mathrm{M}$ and the maximal velocity $\left(V_{\max }\right)$ was $29 \pm 1 \mathrm{nmol} \mathrm{min}{ }^{-1}$ (mg protein $)^{-1}$. Control experiments with solid $\mathrm{NaCl}$ confirmed these results. For all studies, a saturating concentration of $4 \mathrm{mM}$-glycine betaine was used. The transport system had a $\mathrm{pH}$ optimum of $\mathrm{pH} 9 \cdot 1$, with more than $80 \%$ activity between $\mathrm{pH} 8.1$ and $\mathrm{pH} 9 \cdot 4$, and an optimum temperature of $40^{\circ} \mathrm{C}$, with more than $80 \%$ activity between $32^{\circ} \mathrm{C}$ and $52^{\circ} \mathrm{C}$. The theoretically calculated amount of $270 \pm 10 \mathrm{nmol}$ glycine betaine $(\mathrm{mg}$ protein $)^{-1}$ necessary to balance the upshock from $2 \cdot 1 \mathrm{M}$ -
Table 1. Effect of potential metabolic inhibitors on glycine betaine transport by E. halochloris

If not stated otherwise, cells were pre-incubated for $30 \mathrm{~min}$ with the inhibitor before initiation of uptake (with $4 \mathrm{~mm}$-glycine betaine, $40^{\circ} \mathrm{C}$, $\mathrm{pH} 8.7$ ) as described in Methods. For control cells (not exposed to inhibitor) $100 \%$ activity was $29 \mathrm{nmol} \mathrm{min}^{-1}$ (mg protein $)^{-1}$.

\begin{tabular}{lrr}
\hline \hline \multicolumn{1}{c}{ Inhibitor } & Concn & $\begin{array}{c}\text { Percentage } \\
\text { inhibition }\end{array}$ \\
\hline Chloramphenicol & $50 \mu \mathrm{g} \mathrm{ml}^{-1}$ & 0 \\
CCCP & $25 \mu \mathrm{M}$ & 100 \\
CCFP & $25 \mu \mathrm{M}$ & 82 \\
& $100 \mu \mathrm{M}$ & 100 \\
DCCD & $100 \mu \mathrm{M}$ & 30 \\
2,4-DNP & $2 \mathrm{mM}$ & 38 \\
KCN & $1 \mathrm{mM}$ & 5 \\
Sodium azide & $1 \mathrm{mM}$ & 9 \\
Iodoacetate & $1 \mathrm{mM}$ & 0 \\
CDNB & $0.5 \mathrm{mM}$ & 94 \\
PCMB & $0.5 \mathrm{mM}$ & 31 \\
Valinomycin & $45 \mu \mathrm{M}$ & 26 \\
& $100 \mu \mathrm{M}$ & 48 \\
Nigericin & $50 \mu \mathrm{M}$ & 100 \\
Monensin & $14.5 \mu \mathrm{M}$ & 48 \\
& $50 \mu \mathrm{M}$ & 54 \\
& $100 \mu \mathrm{M}$ & 80 \\
\hline \hline
\end{tabular}

to $3 \cdot 1 \mathrm{M}-\mathrm{NaCl}$ was shown to agree with the value of $288 \pm 8 \mathrm{nmol}$ glycine betaine (mg protein) ${ }^{-1}$ determined during uptake experiments. The physiological examinations and the kinetic data indicate the involvement of a transport protein which is activated by osmotic changes. The high intracellular glycine betaine content, as determined by HPLC, implied that uptake must have occurred against an intracellular concentration gradient. Transport against a gradient requires an expenditure of energy. To investigate the source of energy, various metabolic inhibitors were tested (Table 1). 


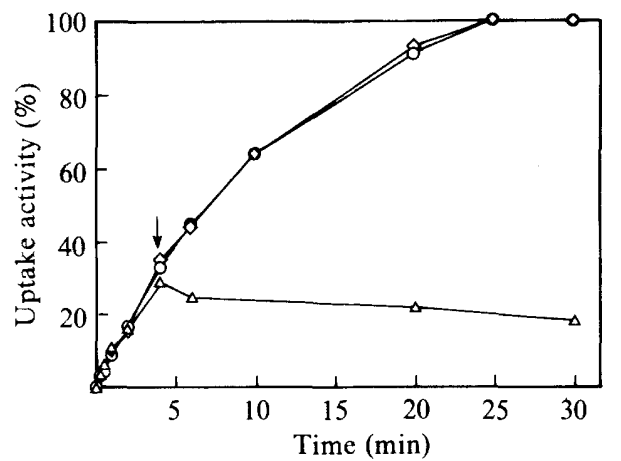

Fig. 3. Effect of $P C M B$ and $C D N B$ on accumulation of glycine betaine by $E$. halochloris. The sulphydryl reagents $(0.5 \mathrm{~mm})$ were added (arrow) after $4 \mathrm{~min}$ accumulation of glycine betaine. Accumulation was measured as described in Methods at $40^{\circ} \mathrm{C}, \mathrm{pH} 8.7$, with 2 mM-glycine betaine. $O$, Control; $\diamond, 0.5 \mathrm{~mm}-\mathrm{PCMB} ; \triangle, 0.5 \mathrm{~mm}$-CDNB.

Addition of the uncouplers CCCP $(25 \mu \mathrm{M})$ and CCFP $(100 \mu \mathrm{M})$, which separate photosynthetic electron transport from photophosphorylation, totally abolished glycine betaine transport. Addition of CCFP $(25 \mu \mathrm{M})$ after 1 min of accumulation stopped further uptake, but did not cause efflux for the next $20 \mathrm{~min}$. The glycolysis inhibitor iodoacetate $(1 \mathrm{~mm})$ had no effect; neither did the cytochrome oxidase inhibitor sodium azide (1 mM) nor the respiration inhibitor potassium cyanide (1 mM). Ethanol, which was used as solvent for some inhibitors, had no effect on transport.

The sulphydryl reagents CDNB $(0.5 \mathrm{mM})$ and PCMB $(0.5 \mathrm{mM})$ were added to cells which had accumulated glycine betaine for $4 \mathrm{~min}$. While PCMB had no effect for the next $20 \mathrm{~min}$, further uptake was inhibited by CDNB, and there was an efflux of glycine betaine for the next $50 \mathrm{~min}$ (Fig. 3). Pre-incubation with CDNB caused $94 \%$ inhibition, whereas PCMB caused only $21 \%$ inhibition. The results obtained with the sulphydryl reagents PCMB and CDNB could be interpreted on the basis of the results obtained by Koo et al. (1991). The rapid loss of glycine betaine in $S$. typhimurium after addition of PCMB led to the postulation of a system that cannot take up glycine betaine and proline, but which, when modified by PCMB, can bring about rapid efflux of these solutes. In E. halochloris an efflux of accumulated glycine betaine was observed after addition of CDNB. The ability of $E$. halochloris to excrete glycine betaine supports the results obtained by Tschichholz \& Trüper (1990). Further experiments are necessary to prove the existence of either one system for uptake and release or of two distinct systems.

Nigericin $(50 \mu \mathrm{M})$, an electroneutral $\mathrm{K}^{+} / \mathrm{H}^{+}$antibiotic ionophore, totally abolished glycine betaine transport. Monensin $(50 \mu \mathrm{M})$, an electroneutral $\mathrm{Na}^{+} / \mathrm{K}^{+}$exchanger, also inhibited transport, but to a lesser extent $(54 \%)$.
Table 2. Effect of various compounds on $\left[{ }^{14} \mathrm{C}\right]$ glycine betaine uptake by E. halochloris

Uptake experiments were performed as described in Methods with $1 \mu \mathrm{M}-\left[{ }^{14} \mathrm{C}\right] \mathrm{glycine}$ betaine at $40^{\circ} \mathrm{C}$ and $\mathrm{pH} 8.7$ with the 'competitor compound' present at $40 \mu \mathrm{M}$ or $2 \mathrm{mM}$. Results are expressed as a percentage of the non-inhibited uptake rate for $1 \mu \mathrm{M}$-glycine betaine: $100 \%$ was $0.078 \mathrm{nmol} \mathrm{m^{-1 }}(\mathrm{mg} \text { protein })^{-1}$.

\begin{tabular}{|c|c|c|}
\hline \multirow[b]{2}{*}{ Compound } & \multicolumn{2}{|c|}{ Percentage inhibition at: } \\
\hline & $40 \mu \mathrm{M}$ & $2 \mathrm{mM}$ \\
\hline Glycine betaine & $35 \cdot 5 \pm 3 \cdot 7$ & $91 \cdot 2 \pm 4.7$ \\
\hline Proline betaine & $22 \cdot 8 \pm 1 \cdot 1$ & $65 \cdot 7 \pm 5 \cdot 7$ \\
\hline Dimethylglycine & $19.8 \pm 0.6$ & $28 \cdot 9 \pm 2 \cdot 2$ \\
\hline Trigonelline & $20 \cdot 3 \pm 1 \cdot 7$ & $31 \cdot 5 \pm 2 \cdot 6$ \\
\hline L-Alanine & $0.8 \pm 0.1$ & $2 \cdot 5 \pm 0.2$ \\
\hline Glycine betaine aldehyde & $2.4 \pm 0.1$ & $-0.3 \pm 0.1$ \\
\hline$\gamma$-Butyrobetaine & $2.7 \pm 0.9$ & $5 \cdot 1 \pm 0 \cdot 2$ \\
\hline$\gamma$-Amino-n-butyrate & $-3.5 \pm 0.9$ & $0.6 \pm 0 \cdot 1$ \\
\hline Sarcosine & $-2.5 \pm 0.5$ & $-7 \cdot 2 \pm 2 \cdot 2$ \\
\hline Choline & $-5 \cdot 9 \pm 0 \cdot 1$ & $-9 \cdot 1 \pm 3 \cdot 6$ \\
\hline Glycine & $-7 \cdot 4 \pm 0.5$ & $-11 \cdot 6 \pm 1 \cdot 2$ \\
\hline Proline & $-4.9 \pm 1.0$ & $-24 \cdot 4 \pm 3 \cdot 0$ \\
\hline
\end{tabular}

Valinomycin $(45 \mu \mathrm{M})$, a $\mathrm{K}^{+}$-specific ionophore, led to a $26 \%$ inhibition of glycine betaine uptake. After $30 \mathrm{~min}$ pre-incubation of photosynthetically active $E$. halochloris in the dark, glycine betaine transport $\left(40{ }^{\circ} \mathrm{C}, \mathrm{pH} 8.7\right.$, $4 \mathrm{~mm}$-substrate) was lowered to $36 \%[100 \%$ activity was $29 \pm 1 \mathrm{nmol} \mathrm{m^{-1 }}$ (mg protein) $)^{-1}$ ], reaching a plateau of $74 \%$ inhibition after $1 \mathrm{~h}$. Supplementing the transport assay with $1 \mathrm{mM}$-ATP had no influence on the transport rate. ATP might not be used directly as an energy source but further studies using cytoplasmic membrane vesicles will be necessary to determine the permeability of the cells to ATP. These results imply that the uptake of glycine betaine is an energy-dependent process. The electrochemical proton gradient, generated by anaerobic photosynthesis, is the main driving force for glycine betaine transport. However, energetic interpretations are made difficult by the fact that any one of the inhibitors used might inhibit various metabolic processes. E. halochloris seems to be able to react to osmotic changes either by active transport within minutes or by new biosynthesis within hours. Active transport may be an efficient adaptive mechanism which allows $E$. halochloris to tolerate drastic changes in water potential due to evaporation and dilution by rain and flooding in their natural habitats, such as alkaline soda lakes (Imhoff et al., 1978), salt lakes and marine sources (Grant et al., 1979; Matheron \& Baulaigue, 1972). This strategy was also suggested for some cyanobacteria that synthesize glycine betaine (Moore et al., 1987).

It would be interesting to investigate the transport upon upshock of the two other compatible solutes, trehalose and ectoine, that are also synthesized by $E$. 


$$
\begin{gathered}
\mathrm{CH}_{3} \\
\mathrm{H}_{+} \\
\mathrm{H}_{3} \mathrm{C}-\mathrm{N}-\mathrm{CH}_{2}-\mathrm{COO}^{-} \\
\mathrm{CH}_{3}
\end{gathered}
$$

Glycine betaine

$$
\mathrm{H}_{3} \mathrm{C}-\mathrm{NH}-\mathrm{CH}_{2}-\mathrm{COOH}
$$

Sarcosine

$$
\mathrm{H}_{3} \stackrel{+}{\mathrm{N}}-\mathrm{CH}_{2}-\mathrm{CH}_{2}-\mathrm{CH}_{2}-\mathrm{COO}^{-}
$$

$\gamma$-Amino-n-butyrate

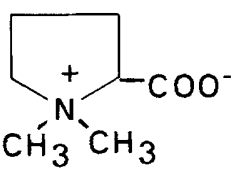

Proline betaine<smiles>C[N+](C)(C)CCCCC(=O)[O-]</smiles>

$\gamma$-Butyrobetaine

Fig. 4. Structure of various compounds used as analogues in glycine betaine transport.

halochloris (Galinski \& Herzog, 1990; Peters et al., 1990). It will also be of interest to examine the properties of the transport protein and the molecular regulation of its expression. Detailed studies in E. coli (May et al., 1986; Barron et al., 1987) and in S. typhimurium (Cairney et al., $1985 a, b$; Sutherland et al., 1986; Higgins et al., 1987) proved the existence of a low-affinity system, ProP, and a high-affinity transport system, ProU, which is induced by high osmolarities. The proU gene of these bacteria encodes a periplasmic betaine binding protein with a molecular mass of about $32 \mathrm{kDa}$ (May et al., 1986; Cairney et al., 1985a). Only recently, a periplasmic binding protein was identified in $R$. meliloti (Le Rudulier et al., 1991) and $A$. brasilense sp7 (Riou et al., 1991). It remains to be shown whether the ProP and ProU systems are involved in glycine betaine transport in $E$. halochloris.

\section{Structural specificity of glycine betaine transport}

The structural specificity of the glycine betaine transport system was tested by examining the effect of various nonradioactive competitors (Table 2). Uptake of radioactive glycine betaine was measured in the presence of competitor concentrations 40- and 2000-fold in excess of the glycine betaine concentration $(1 \mu \mathrm{M})$.

Transport was not affected by L-alanine, glycine betaine aldehyde and $\gamma$-amino-n-butyrate. Choline, glycine and sarcosine caused slight stimulation of transport, but the most notable stimulation was found with proline (2000-fold excess, $24 \%$ stimulation). The most competent negative effector was proline betaine, with $66 \%$ inhibition at a concentration of $2 \mathrm{mM}$, whereas dimethylglycine and trigonelline caused only $29 \%$ and $32 \%$ inhibition at the same concentration. With respect to the structural specificity of the uptake system (Fig. 4), a carboxyl group seems to be of great importance because glycine betaine aldehyde had no effect whereas choline stimulated uptake $(9 \%$ at $2 \mathrm{~mm})$. Glycine (without any methyl group) stimulated glycine betaine uptake, whereas dimethylglycine ( $2 \mathrm{~mm}$ ) caused $29 \%$ inhibition. Proline had no inhibitory effect whereas proline betaine, which possesses two methyl groups, caused the greatest inhibition. $\gamma$-Butyrobetaine, choline and L-alanine, possessing more backbone carbon atoms than glycine betaine, had no inhibitory effects.

These results indicate that glycine betaine uptake shows considerable structural specificity, especially with respect to the presence of a carboxyl group and the constellation of the carboxyl to the methyl group. Chemical modification of the relevant carboxyl group might reveal more about its importance for glycine betaine recognition. Rowland \& Tristram (1975) reported a proline transport system in E. coli, in which a carboxyl group binds by a hydrogen bond to the protein binding site.

\section{Constitutivity of the glycine betaine transport system}

The immediate stimulation of transport after osmotic upshock indicated that the system is activated and not induced by osmotic stress. Addition of chloramphenicol $\left(50 \mu \mathrm{g} \mathrm{ml}^{-1}\right)$, which inhibits de novo protein synthesis and cell growth, had no effect on uptake, indicating that the transport system is constitutive.

This study was supported by a grant from the German-Israeli Foundation for Scientific Research and Development (GIF). P. Peters gratefully acknowledges the great hospitality extended to her during her stay in Rehovot, Israel. Thanks are due to Wolfgang Hipp for valuable scientific discussions.

\section{References}

Abee, T., Palmen, R., Hellingwerf, K. J. \& Konings, N. W. (1990). Osmoregulation in Rhodobacter sphaeroides. Journal of Bacteriology 173, 229-233

Barron, A., Jung, J. U. \& Villarejo, M. (1987). Purification and characterization of a glycine betaine binding protein from Escherichia coli. Journal of Biological Chemistry 262, 11841-11846.

BorowitzKA, L. J. (1980). Solute accumulation and regulation of cell water activity. In The Physiology and Biochemistry of Drought Resistance in Plants, pp. 97-130. Edited by L. B. Paleg \& D. Aspinall. Sydney, Australia: Academic Press.

Brown, A. D. (1976). Microbial water stress. Bacteriological Reviews 40, 803-846. 
CaIRnEY, J., Booth, I. R. \& Higgins, C. F. (1985a). Osmoregulation of gene expression in Salmonella typhimurium: proU encodes an osmotically induced betaine transport system. Journal of Bacteriology 164, 1224-1232.

Cairney, J., Booth, I. R. \& Higgins, C. F. (1985b). Salmonella typhimurium encodes a transport system for the osmoprotectant betaine. Journal of Bacteriology 164, 1218-1223.

Cromwell, B. T. \& RenNie, S. D. (1953). The biosynthesis and metabolism of betaines in plants. Biochemical Journal 55, 189-192.

FoUGÈRE, F. \& LE RUDULIER, D. (1990). Uptake of glycine betaine and its analogues by bacteroids of Rhizobium meliloti. Journal of General Microbiology 136, 157-163.

GabBay-AzARIA, R., Tel-Or, E. \& SchöNFeld, M. (1988). Glycinebetaine as an osmoregulant and compatible solute in the marine cyanobacterium Spirulina subsalsa. Archives of Biochemistry and Biophysics 264, 333-339.

GaLINSKI, E. A. (1986). Salzadaptation durch kompatible Solute bei halophilen phototrophen Bakterien. Doctoral thesis, University of Bonn, Germany.

GALINSKI, E. A. (1987). Halo-fermentation, a novel low water process for the production of organic chemicals and enzyme protective agents. In Bioreactors and Biotransformation, pp. 201-212. Edited by G. W. Moody \& P. B. Baker. Amsterdam: Elsevier.

Galinski, E. A. \& Herzog, R. M. (1990). The role of trehalose as a substitute for nitrogen-containing compatible solutes (Ectothiorhodospira halochloris). Archives of Microbiology 153, 607-613.

GALINSKI, E. A. \& TRÜPER, H. G. (1982). Betaine, a compatible solute in the extremely halophilic phototrophic bacterium Ectothiorhodospira halochloris. FEMS Microbiology Letters 13, 357-360.

Grant, W. D., Mills, A. A. \& Schofield, A. K. (1979). An alkalophilic species of Ectothiorhodospira from a Kenyan soda lake. Journal of General Microbiology 110, 137-142.

HANES, C. S. (1932). Studies on plant amylases. Biochemical Journal 26, 1406-1421.

Higgins, C. F., Cairney, J., Stirling, D. A., Sutherland, L. \& BooTH, I. R. (1987). Osmotic regulation of gene expression: ionic strength as an intracellular signal. Trends in Biochemical Sciences 12, 339-344.

Hutkins, R. W., Ellefson, W. L. \& Kashet, E. R. (1987). Betaine transport imparts osmotolerance on a strain of Lactobacillus acidophilus. Applied and Environmental Microbiology 53, 2275-2281.

Ikuta, S., Matuura, K., Imamura, S. \& Horituti, Y. (1977). Oxidative pathway of choline to betaine in the soluble fraction prepared from Arthrobacter globiformis. Journal of Biochemistry 82, 157-163.

IMHOFF, J. F. \& Rodriguez-VALERA, F. (1984). Betaine is the main compatible solute of halophilic eubacteria. Journal of Bacteriology $160,478-479$.

IMHOFF, J. F. \& TRÜPER, H. G. (1977). Ectothiorhodospira halochloris sp. nov., a new extremely halophilic phototrophic bacterium containing bacteriochlorophyll b. Archives of Microbiology 114, 115121

IMHOFF, J. F., HASHWA, F. F. \& TRÜPER, H. G. (1978). Isolation of extremely halophilic phototrophic bacteria from the alkaline Wadi Natrun, Egypt. Archives of Hydrobiology 84, 381-388.

Ken-Dror, S., Preger, R. \& AVI-Dor, Y. (1986). Role of betaine in the control of respiration and osmoregulation of a halotolerant bacterium. FEMS Microbiology Reviews 39, 115-120.

Koo, S.-P., Higgins, F. \& BоOTH, I. R. (1991). Regulation of compatible solute accumulation for a glycine betaine efflux system. Journal of General Microbiology 137, 2617-2625.
Le Rudulier, D. \& Bouillard, L. (1983). Glycine betaine, an osmotic effector of Klebsiella pneumoniae and other members of the Enterobacteriaceae. Applied and Environmental Microbiology 46, 152 159.

Le Rudulier, D., Yang, S. S. \& Csonka, L. N. (1982). Nitrogen fixation in Klebsiella pneumoniae during osmotic stress. Effect of exogenous proline or a proline overproducing plasmid. Biochimica et Biophysica Acta 719, 273-283.

Le Rudulier, D., Gloux, K. \& Riou, N. (1991). Identification of an osmotically induced periplasmic glycine betaine-binding protein from Rhizobium meliloti. Biochimica et Biophysica Acta 1061, 197 205

Matheron, R. \& Baulaigue, R. (1972). Bactéries photosynthétiques sulfureuses marines. Assimilation des substances organiques et minérales et influence de la tenuer en chlorure de sodium du milieu de culture sur leur développement. Archives of Microbiology 86, 291304.

May, G., FaAtz, E., Villarejo, M. \& Bremer, E. (1986). Binding protein dependent transport of glycine betaine and its osmotic regulation in Escherichia coli K12. Molecular and General Genetics 205, 225-233.

MEYER, B. (1987). ATPase und ATP-Synthese in Ectothiorhodospira halochloris. Doctoral thesis, University of Bonn, Germany.

Mohammad, F. A. A., Reed, R. H. \& Stewart, W. D. P. (1983). The halophilic cyanobacterium Synechocystis DUN 52 and its osmotic responses. FEMS Microbiology Letters 16, 287-290.

Moore, D. J., ReED, R. H. \& Stewart, W. D. P. (1987). A glycine betaine transport system in Aphanothece halophytica and other glycine betaine-synthesizing cyanobacteria. Archives of Microbiology 147, 399-405.

OREN, A. (1990). Formation and breakdown of glycine betaine and trimethylamine in hypersaline environments. Antonie van Leeuwenhoek 58, 291-298.

Peters, P., Galinski, E. A. \& TRÜPER, H. G. (1990). The biosynthesis of ectoine. FEMS Microbiology Letters 71, 157-162.

PIERCE (1989), Review of assay protocol. In BCA Protein Assay Reagent, pp. 1-13. Pierce: USA

Riou, N., Poggi, M. C. \& Le Rudulier, D. (1991). Characterization of an osmoregulated periplasmic glycine betaine-binding protein in Azospirillum brasilense sp7. Biochimie 73, 1187-1193.

Robertson, D. E., Roberts, M. F., Belay, N., Stetter, K. \& Boone, D. R. (1990). Occurrence of $\beta$-glutamate, a novel osmolyte, in marine methanogenic bacteria. Applied and Environmental Microbiolgy 56, 1504-1508.

Rowland, I. \& Tristram, H. (1975). Specificity of the Escherichia coli proline transport system. Journal of Bacteriology 123, 871-877.

Severin, J., Wohlfarth, A. \& Galinski, E. A. (1992). The predominant role of recently discovered tetrahydropyrimidines for the osmoadaptation of halophilic eubacteria. Journal of General Microbiology 138, 1629-1638.

Sutherland, L., Cairney, J., Elmore, M. J., Booth, I. R. \& Higgins, C. F. (1986). Osmotic regulation of transcription: induction of the pro $U$ betaine transport gene is dependent on accumulation of intracellular potassium. Journal of Bacteriology 168, 805-814.

TSCHICHHOLZ, I. \& TRÜPER, H. G. (1990). Fate of compatible solutes during dilution stress in Ectothiorhodospira halochloris. FEMS Microbiology Ecology 73, 181-186.

WARBurG, O. \& Christian, W. (1941). Isolierung und Kristallisation des Gärungsfermentes Enolase. Biochemische Zeitschrift 310, 384 421. 